\title{
Cultivation of carp fish in polyculture using soy milk in saltwater drainage system of Uzbekistan
}

\author{
$N$. Tosheva ${ }^{1, *}, O$. Nosirov $^{2}, M$. Yuldashov $^{1}$, and $B$. Kamilov $^{1}$ \\ ${ }^{1}$ Tashkent State Agrarian University, University str., 2, Tashkent province, Uzbekistan, 100140 \\ ${ }^{2}$ Bukhara State University, Muhammad Ikbol str., 11, Bukhara province, Uzbekistan, 105018
}

\begin{abstract}
In this paper, a new type of fertilizer/feed for Uzbekistan were developed when growing fry to underyearlings. In four experimental nursery ponds (1-3 ha each) with brackish water (2.5 - 3.9\%o), cultured carp fish were grown in a pond polyculture using mineral fertilizers and wheat bran soaked in soy milk. In different variants, the total fish productivity was $27-48.9 \mathrm{q} / \mathrm{ha}$, underyearlings of all species reached an average weight of more than $100 \mathrm{~g}$, the yield was $76-88 \%$, provided that they were stocked with 5-10 gram fry in early July. Juveniles of cyprinids can be successfully reared in brackish water fed from a collector-drainage system in Uzbekistan.
\end{abstract}

\section{Introduction}

In a pond polyculture of carp fish in a temperate climate (by the example of Uzbekistan), a two-year turnover is adopted, in which in the first growing season, underyearlings with a final normative average individual body weight of $25 \mathrm{~g}$ are raised at the end of October when transplanted into wintering ponds $[1,2]$. To ensure the growth of juveniles, the most important factor is to stimulate the development of organisms of a natural food base in the pond; this is achieved through the introduction of organic and mineral fertilizers. In a semi-intensive system, together with fertilizers, starting from the planting of fry of cultured cyprinids in polyculture, additional cereal-based feedstuffs with a protein content of 11$21 \%$ is used. The normative fish productivity in the conditions of the VII zone of fish farming is an indicator of $20-25 \mathrm{~kg} / \mathrm{ha}[3,5]$. The search for new types of feed and fertilizers represents an important research perspective for optimizing the technology of carp pond polyculture. In recent years, attention has been drawn to the use of soy milk for the cultivation of fish seed, developed in China [3,6].

A significant limitation for arid countries is the attachment of the technology of rearing juveniles to fresh water, as a result of which a significant part of the republic's water resources, namely the collector-drainage system, is not used to create nursery ponds $[4,7]$. Taking into account the above, in 2019, in the newly created fish farm LLC "Navruz kut barakasi", which created nursery ponds on the banks of the Central Golodnostep Gollector (CGC) with drainage brackish water, innovative cultivation of fish seed for carp fish using soy milk, was carried out.

\footnotetext{
${ }^{*}$ Corresponding author: n.n.tosheva@yandex.com
} 
The aim of this work was to determine the growth and fish productivity of rearing ponds with brackish water using soy milk.

\section{Materials and methods}

In 2019, free embryos of silver carp - Hypophthalmichthys molitrix and carp - Cyprinus carpio were grown in monoculture in the growing ponds No. 1 (1 ha), 2 ( 3 ha), 3 (1.1 ha), 4 (3 ha), grass carp - Ctenopharyngodon idella, silver carp - Hypophthalmichthys nobilis, to fry, and from the beginning of July juveniles of different species were mixed, creating a polyculture with a different ratio of different species, and grown until the end of October. Manure, as well as ammonium nitrate and ammophos, were introduced into the ponds, focusing on the transparency of the water as an indicator of the development of the natural forage base. Wheat bran was soaked daily with soy milk, which was introduced into the pond, while $15 \%$ of the daily ration of bran was granulated into granules with a diameter corresponding to the size of the fish (Sbornik ..., 1986). No other feed was used. Control catches were carried out 2 times a month, total fishing of ponds was carried out on October 30 . The average individual body weight and limits were determined for randomly selected at least 500 individuals.

The indicators of the fishery quality of water in the ponds were measured using a portable thermos-oximeter "HANNA HI 9147", $\mathrm{pH}$ - using a portable $\mathrm{pH}$ meter "pHscan 30S" $[8,9]$.

\section{Results}

In ponds during July - October, the $\mathrm{pH}$ value varied from 6.9 to 8.1 , the salinity of the water in the pond varied from 2.6 to $3.5 \%$, i.e. was brackish. The content of dissolved oxygen throughout the growing season varied within $3.5-5.9 \mathrm{mg} / \mathrm{l}$. The indicators corresponded to the norms of the carp pond polyculture. The water temperature in the canal and ponds in June - September varied from $15.6-29.6^{\circ} \mathrm{C}$, in October it dropped to $13-24^{\circ} \mathrm{C}$.

Manure was introduced before stocking the prelarvae at the end of May when larvae of different species were reared in monoculture, but the effect of manure decomposition could continue in the future when underyearlings were reared in the same ponds in polyculture.

The amount of mineral fertilizers applied to the ponds is shown in Table 1. Fertilizers were applied as needed to stimulate the development of plankton, determined by constant research monitoring.

Table 1. Fertilization in nursery ponds

\begin{tabular}{|c|c|c|c|c|c|}
\hline \multirow{2}{*}{$\begin{array}{c}\text { Fertilizer type, unit } \\
\text { measurements }\end{array}$} & \multirow{2}{*}{ Months } & \multicolumn{4}{|c|}{ Pond \# } \\
\cline { 3 - 6 } & & $\mathbf{1}$ & $\mathbf{2}$ & $\mathbf{3}$ & $\mathbf{4}$ \\
\hline Manure, $\mathrm{kg} / \mathrm{ha}$ & June & 500 & 170 & 900 & 170 \\
\hline \multirow{4}{*}{ Ammophos, kg/ha } & July & 150 & 150 & 100 & 50 \\
\cline { 2 - 6 } & August & 100 & 50 & 100 & 70 \\
\cline { 2 - 6 } & September & 100 & 70 & 100 & 80 \\
\cline { 2 - 6 } & October & 100 & 70 & 100 & 70 \\
\cline { 2 - 6 } & Total & $\mathbf{4 5 0}$ & $\mathbf{3 7 0}$ & $\mathbf{3 7 0}$ & $\mathbf{3 0 0}$ \\
\hline \multirow{3}{*}{$\begin{array}{c}\text { Ammonium nitrate, } \\
\mathrm{kg} / \mathrm{ha}\end{array}$} & July & 200 & 30 & 150 & 50 \\
\cline { 2 - 6 } & August & 100 & 80 & 100 & 70 \\
\cline { 2 - 6 } & September & 100 & 80 & 100 & 100 \\
\cline { 2 - 6 } & October & 100 & 70 & 100 & 70 \\
\hline
\end{tabular}




\begin{tabular}{|l|l|l|l|l|l|}
\hline & Total & $\mathbf{5 0 0}$ & $\mathbf{3 0 0}$ & $\mathbf{4 0 0}$ & $\mathbf{3 0 0}$ \\
\hline
\end{tabular}

The most demanded at present for the cultivation of marketable fish is silver carp, whose share in fish production is $90 \%$ or more. Proceeding from this, in ponds 2 and 4 , we created a very high proportion of this species when stocking fry (Table 2). Carp is very popular in the republic, it has already become noticeable to master the cultivation of carp in cages, i.e. the demand for this type of planting material may increase sharply in the near future. Proceeding from this, in ponds No. 3 and 1, we made a great deal of emphasis on carp. The silver carp and grass carp are additional fish in the applied technology, as a result of which we stocked these species as additional fish in all ponds.

Numerically, the yield of underyearlings by species and in general for ponds when rearing fry for different species was $71-88 \%$, moreover, for more massive (i.e., with which fish farmers of the republic have a lot of practice) silver carp and carp, the yield was more than $80 \%$ (Table 2).

Table 2. Stocking rates and fish yield in rearing experimental ponds

\begin{tabular}{|c|c|c|c|c|c|}
\hline \multirow{2}{*}{ Indicators } & \multirow{2}{*}{$\begin{array}{l}\text { Sort of spe- } \\
\text { cies }\end{array}$} & \multicolumn{4}{|c|}{ Pond \# } \\
\hline & & 1 & 2 & 3 & 4 \\
\hline \multirow{5}{*}{ Stocking, '000 units/ha } & $\mathrm{SC}$ & 5.9 & 28.1 & 5.2 & 20.2 \\
\hline & $\mathrm{BC}$ & 2.1 & 8.0 & 4.3 & 6.4 \\
\hline & $\mathrm{GC}$ & 2.5 & 4.8 & 3.7 & 2.1 \\
\hline & C & 18.4 & 2.7 & 45.0 & 2.3 \\
\hline & Total & 28.9 & 43.7 & \begin{tabular}{|l|}
58.1 \\
\end{tabular} & 30.9 \\
\hline \multirow{5}{*}{ Output, '000 pcs/ha } & $\mathrm{SC}$ & 5.2 & 24.7 & 4.5 & 17.8 \\
\hline & $\mathrm{BC}$ & 1.6 & 6.1 & 3.3 & 4.8 \\
\hline & $\mathrm{GC}$ & 2.0 & 3.8 & 2.9 & 1.6 \\
\hline & $\mathrm{C}$ & 14.9 & 2.2 & 36.5 & 1.8 \\
\hline & Total & 23.7 & 36.8 & 47.2 & 26.1 \\
\hline \multirow{5}{*}{ Output, q/ha } & $\mathrm{SC}$ & 7.5 & 25.6 & 6.7 & 17.8 \\
\hline & $\mathrm{BC}$ & 4 & 9.1 & 8.2 & 7.3 \\
\hline & $\mathrm{GC}$ & 3.9 & 8.8 & 5.9 & 3.9 \\
\hline & $\mathrm{C}$ & 11.2 & 4.5 & 28.3 & 3.7 \\
\hline & Total & 27.4 & 48.1 & 48.8 & 32.7 \\
\hline
\end{tabular}

The fish productivity of the nursery ponds was $27.4-48.9 \mathrm{q} / \mathrm{ha}$, while the productivity of silver carp and carp in the hotel ponds reached 25.6 and $28.3 \mathrm{q} / \mathrm{ha}$, respectively (Table 3).

Table 3. Fish productivity of nursery ponds by species and total in experiments

\begin{tabular}{|c|c|c|c|c|}
\hline \multirow{2}{*}{ Sort of species } & \multicolumn{4}{|c|}{ Pond \# } \\
\cline { 2 - 5 } & $\mathbf{1}$ & $\mathbf{2}$ & $\mathbf{3}$ & $\mathbf{4}$ \\
\hline SC & 7.5 & 25.6 & 6.6 & 17.7 \\
\hline BC & 4.0 & 9.2 & 8.2 & 7.3 \\
\hline GC & 3.9 & 8.8 & 5.9 & 3.9 \\
\hline C & 11.9 & 4.5 & 28.3 & 3.7 \\
\hline Total & $\mathbf{2 7 . 4}$ & $\mathbf{4 8 . 1}$ & $\mathbf{4 8 . 9}$ & $\mathbf{3 2 . 7}$ \\
\hline Note: SC - Silver Carp, BC - Bighead Carp, GC - Grass Carp, C - Carp \\
\hline
\end{tabular}

Correlation analysis showed that there was no relationship between the amount of ammophos introduced into ponds during the growing season (per $1 \mathrm{ha}$ ) and the total fish 
productivity $(\mathrm{R}=-0.25)$. Also, there was no significant correlation between the total amount of applied ammonium nitrate and the total fish productivity of ponds $(\mathrm{R}=-0.35)$. At the same time, a strong positive relationship was revealed between the total amount of applied mineral fertilizers (ammophos + nitrate) and the total fish productivity, which is shown in Figure 1.

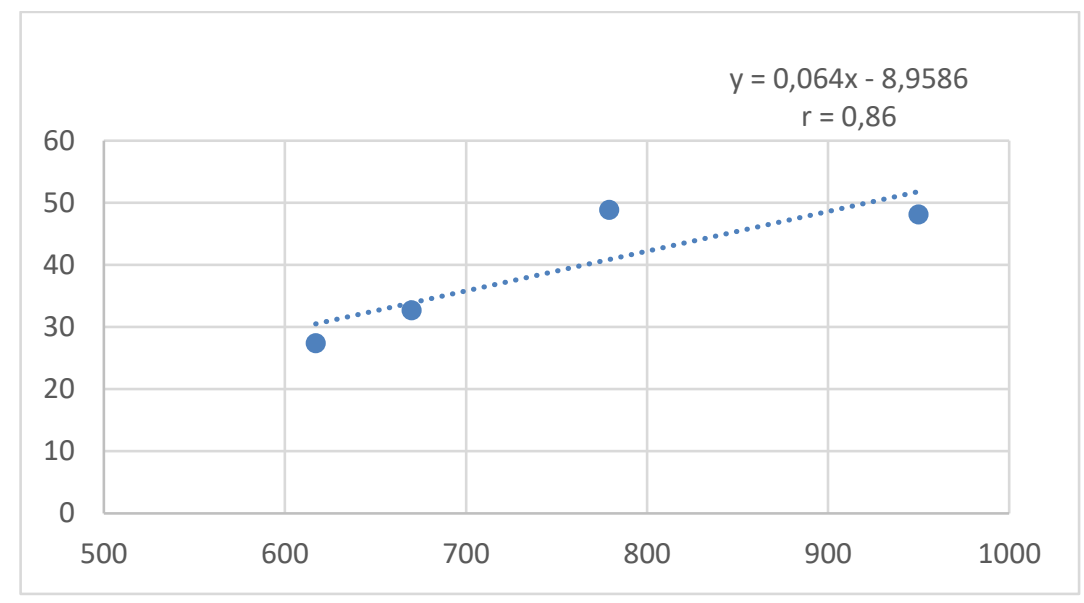

Fig. 1. Dependence of the total fish productivity of rearing ponds (y) on the total amount of applied mineral fertilizers $(\mathrm{x})$

Correlation analysis also revealed that there was a strong positive relationship between the fish stocking density (the number of fish per unit of pond area) and the total fish productivity of ponds (Figure 2). At the same time, there was no correlation between the total fish productivity of the ponds and the relative amount of applied bran soaked in soy milk $(\mathrm{R}=0.07)$.

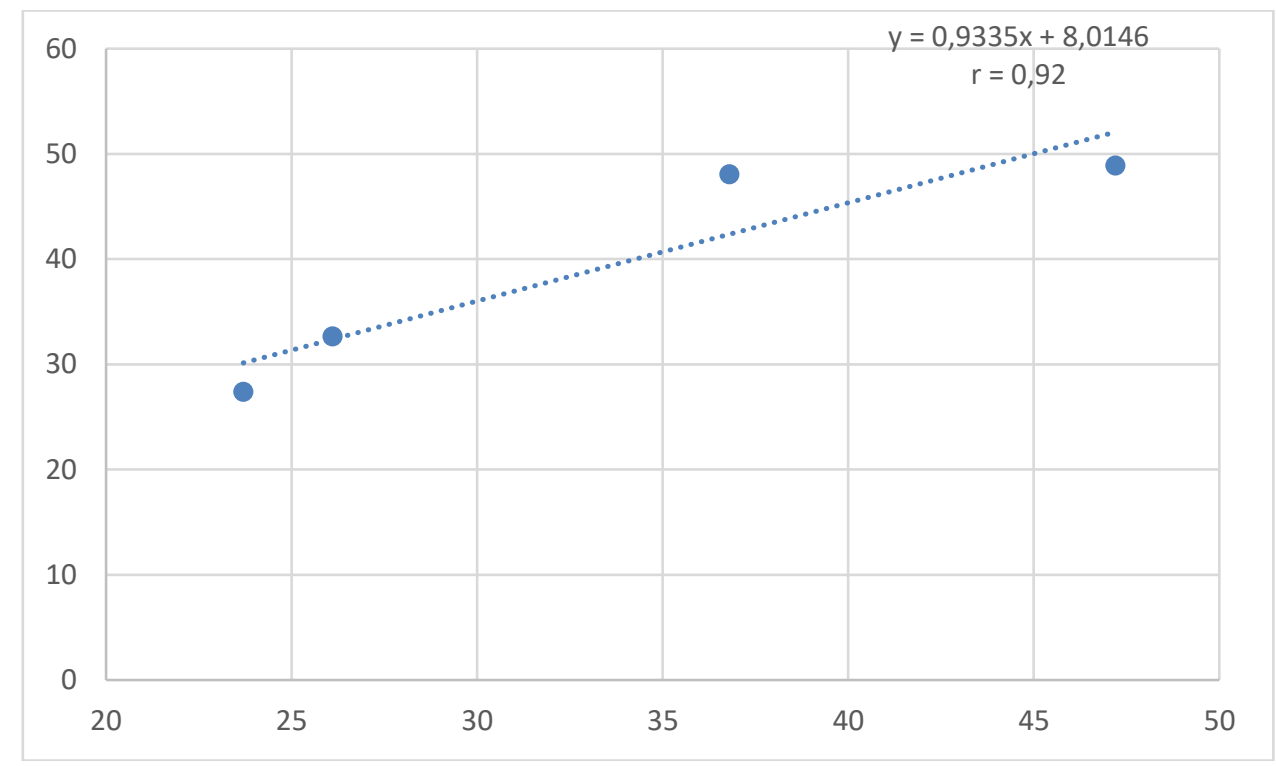

Fig. 2. Dependence of the total fish productivity of nursery ponds (y) on the fish stocking density (x) 


\section{Discussion and conclusion}

One of the priority areas of research to optimize the biotechnology of pond polyculture is the search for new types of feed. Also, a promising direction is research on the possibility of adapting the passage of cultured freshwater fish to the initial stages of the life cycle (i.e. carrying out fish-breeding cycles) in a drainage system, which is characterized by brackish water, a relatively constant level of surface runoff throughout the year and not using this type of water resources in the economy (i.e., it is a resource for increasing fish production in the country).

Note that the standard indicators for the cultivation of underyearlings of cyprinids are: total fish productivity $24-25 \mathrm{q} /$ ha (including carp 12.6, silver carp - 9.9, grass carp and silver carp $0.9 \mathrm{q} / \mathrm{ha}$ ), the average individual body weight of underyearlings is $25 \mathrm{~g}$, the standard yield of underyearlings when planting fry is $40-50 \%$. In our experiments, fish productivity was obtained in different variants of $27-48.9$ q/ha, fish of all species reached an average weight of more than $100 \mathrm{~g}$. The yield of underyearlings was $76-88 \%$, provided that they were stocked with 5-10 gram fry in early July.

Based on the peculiarities of the biology of cultured cyprinids, feeding two-year-old carp pond polyculture on drainage water is used both in several countries of the world (China, Egypt, etc.) [6] and in Uzbekistan. However, it was believed that in the early stages fry require fresh water, as a result of which fish hatcheries of the republic are concentrated in the eastern (foothill) zones of Uzbekistan.

As our experience has shown, juveniles of cyprinids can be successfully reared in brackish water; the water of the CGC throughout the growing season had a salinity of $2.5-3.9$ $\%$. In our case, free embryos were immediately brought to ponds with brackish water, where they were grown for the entire first year of life.

The use of soy milk began to develop in China, especially when rearing prelarvae to fry. In China, soy milk is used, indicating that it is a good fertilizer for the development of a natural food base $[3,6]$. Our data suggest that soy milk has a complex positive effect on the growth of the generation of all cultured cyprinids. In fact, starting with the fry, only mineral fertilizers and wheat bran soaked in soy milk were introduced into the pond. At the same time, there were quite massive fish stocks in the ponds, as evidenced by the final overall fish productivity. Carp and, in part, grass carp immediately ate the bran soaked in highprotein soy milk, and two species of silver carp grew well, which means there was sufficient development of the natural fodder base of the ponds.

Fish quickly grew in all variants, including those with a significant predominance of carp or silver carp. The high overall fish productivity of ponds depended positively most of all on the fish stocking density: the more fish were placed in the pond, the higher the productivity became, i.e. the fodder base in the pond was enough even for such a high productivity as $41-48 \mathrm{~kg} / \mathrm{ha}$. Also, the total fish productivity positively strongly depended on the total amount of applied mineral fertilizers during the season. At the same time, we note that the fish farmer applied fertilizers to the pond as needed, i.e. when monitoring showed a decrease in the natural food supply in the pond.

Thus, in drainage systems it is possible to successfully cultivate underyearlings of cultured cyprinids, and soy milk is a promising new type of fertilizer/feed for these fish. It is possible to recommend stocking density when stocking fry in general 40 - 60 thousand pieces/ha. 


\section{References}

1. B. G. Kamilov, R. B. Kurbanov, T. V. Salikhov, Fishery - carp fish farming in Uzbekistan, 33 (ChinorERK, Tashkent, 2003)

2. Z. A. Mustafaeva, B. G. Kamilov, A. N. Abdurakhimova, U. T. Mirzaev, J. Scientific Works 2(48), 10-16 (2019)

3. Z. A. Mustafaeva, U. T. Mirzaev, B. G. Kamilov, Methods of hydrobiological monitoring of water bodies in Uzbekistan, 112 (Navrus Press, Tashkent, 2017)

4. R. Kulmatov, A. Taylakov, S. Khasanov, Environmental Science and Pollution Research, 1-11 (2021)

5. W. C. Valenti, D. L. Flickinger, Fisheries and Aquaculture 9, 207 (2020)

6. J. F. Gui, Q. Tang, Z. Li, J. Liu, S. S. De Silva, Aquaculture in China: success stories and modern trends (John Wiley and Sons, 2018)

7. R. A. Kulmatov, S. A. Adilov, S. Khasanov, In IOP Conference Series: Earth and Environmental Science 614(1), 012149 (2020)

8. P. Jayasankar, K. N. Mohanta, S. Ferosekhan, Aquaculture in India, 23-49 (2018)

9. G. Caruso, R. Caruso, G. Sarà, J Clin Microbiol Biochem Technol 6(1), 14-28 (2020) 